Bangladesh J. Bot. 49(3): 643-651, 2020 (September)

\title{
EFFECTS OF NAA AND NITROGEN FERTILIZER ON NPK UPTAKE AND NITROGEN USE EFFICIENCY OF BARI GOM-25 (TRITICUM AESTIVUM L.)
}

\author{
AMM Golam Adam* ${ }^{1}$, Nargis Jahan and Parveen Rashid \\ Department of Botany, University of Dhaka, Dhaka-1000, Bangladesh
}

Keywords: Triticum aestivum, Nitrogen fertilizer, NPK uptake, NUE, Sowing time

\begin{abstract}
Effects of NAA (both as seed soaking and foliar spray) in combination with nitrogen fertilizer (0, 25, 50, 75 and $100 \%$ of recommended dose) on NPK uptake and nitrogen use efficiency (NUE) of BARI Gom-25 at flowering, grain filling, harvest and two sowing time (November 15 and 22) were evaluated. At flowering stage, significantly higher NPK uptake by shoot and root was obtained from seed soaking in 10 ppm NAA in combination with $75 \% \mathrm{~N}$ fertilizer $\left(\mathrm{SOF}_{3}\right)$ in both the sowing time with a few exceptions. But at grain filling stage, significantly higher NPK uptake by both shoot and root and N uptake by root was recorded from seed soaking in 10 ppm NAA in combination with $100 \% \mathrm{~N}$ fertilizer $\left(\mathrm{SOF}_{4}\right)$ followed by $\mathrm{SOF}_{3}$ treatment. In comparison to full dose of $\mathrm{N}$ fertilizer, significantly higher NPK uptake by shoot, root and grain was also recorded from $\mathrm{SOF}_{3}$ treatment in most of the cases. Findings indicated that NAA treatment at varying N-level had better stimulation on $\mathrm{N}$ and $\mathrm{P}$ uptake when sown on November 15 than November 22. However, the trend was reverse in case of K uptake. The NUE was significantly influenced by NAA at various N-levels. At flowering stage, significantly higher NUE of shoot and total plant was obtained from $\mathrm{SOF}_{3}$ treatment in both sowing times. Whereas at grain filling stage, the same response was recorded from seed soaking in $10 \mathrm{ppm}$ NAA in combination with $25 \% \mathrm{~N}$ fertilizer $\left(\mathrm{SOF}_{1}\right)$. Foliar application of $20 \mathrm{ppm}$ NAA in combination with $25 \% \mathrm{~N}$ fertilizer $\left(\mathrm{SSF}_{1}\right)$ also resulted significantly higher $\mathrm{NUE}$ of root at both flowering and grain filling and those of shoot, grain and total plant with a few exceptions at harvest.
\end{abstract}

\section{Introduction}

Nitrogen is required by plants in comparatively larger amounts than the other essential nutrients. The amount of $\mathrm{N}$ fertilizer applied to plants must be carefully managed to ensure that it will be available throughout the growing season so that vegetative and reproductive development is not restricted (Vidal et al. 1999). Crops are often fertilized with large amounts of $\mathrm{N}$ fertilizer, but only a small fraction of this (roughly 5 - 50\%) is taken up by the plants (Carranca 2012). Applied $\mathrm{N}$ is not taken up by the crop or immobilized in the soil but it is lost by volatilization, denitrification, leaching and runoff (Canfield et al. 2010). The $\mathrm{N}$ losses can be reduced by enhancing the plants' $\mathrm{N}$ uptake efficiency, which greatly affects the overall nitrogen use efficiency (NUE) of a crop. Moreover, higher NUE by plants could reduce fertilizer input costs, decrease the rate of nutrient losses and enhance crop yields.

Reports revealed that application of optimum dose of NAA, alone or in combination with N fertilizer had pronounced effect as growth promoter on growth, yield and biochemical processes of major cereal crops viz. rice (Adam and Jahan 2011, Jahan and Adam 2014), wheat (Jahan and Adam 2013, Islam and Jahan 2016a), maize (Akter 2016). However, reports regarding the effect of NAA on nutrient uptake and NUE by cereal crops are scanty in Bangladesh (Adam et al. 2012, Islam and Jahan 2016b). In addition, no report is available on the responses of NAA at various doses of $\mathrm{N}$ fertilizer on nutrient uptake and fertilizer use efficiency by any variety of wheat in relation to sowing time. Thus, an attempt was taken to evaluate the effect of NAA both as seed

*Author for correspondence: <adam_du04@yahoo.com>. 'Department of Botany. Jagannath University, Dhaka-1100, Bangladesh. 
soaking and foliar spray treatments in combination with different doses of N fertilizer on NPK uptake and NUE of a high yielding variety of wheat (var. BARI Gom-25) at two sowing time.

\section{Materials and Methods}

A field experiment on BARI Gom-25 was conducted at the Botanical garden of the Department of Botany, University of Dhaka during 2016 - 2017. The experiment was laid out in RBD, replicated four times. The total area of the experimental field was $98.56 \mathrm{~m}^{2}$ which was divided into two plots. Each plot was again divided into 36 sub-plot having net size of approximately $0.32 \mathrm{~m}^{2}$ maintaining sub-plot to sub-plot distance of $50 \mathrm{~cm}$. Preparation of experimental field was done conventionally. Nitrogen $(\mathrm{N})$, phosphorus $(\mathrm{P})$ and potassium $(\mathrm{K})$ content of experimental soil were determined following standard methods (Murphy and Riley 1962, Jackson 1973, Marr and Cresser 1983). Initial status of soil indicates the presence of low amount of nitrogen, very high amount of phosphorus and very low amount of potassium. Cowdung was mixed thoroughly (4 ton/ha) and muriate of potash, gypsum and boric acid were applied at doses recommended by Fertilizer Recommendation Guide (2012). Two-thirds of urea and full of the other fertilizers were applied as basal dose during final land preparation. The remaining urea was applied immediately after the first irrigation at the age of 18 days.

Seeds of BARI Gom- 25 were sterilized with $0.5 \%$ calcium hypochlorite followed by soaking in $10 \mathrm{ppm}$ NAA for $12 \mathrm{hrs}$ and then sown in lines $20 \mathrm{~cm}$ apart maintaining plant to plant distance of $10 \mathrm{~cm}$ at two sowing time viz. November 15 (timely sown) and November 22 (7 days late sown). Cultural practices viz. thinning, irrigation, weeding etc. were done following methods quoted in Handbook of Agricultural Technology (Chowdhury and Hassan 2013). This trial consisted of nine treatments viz. control $=$ No NAA and $\mathrm{N}$ fertilizer; $\mathrm{F}_{4}=100 \% \mathrm{RDN}$ (recommended dose of $\mathrm{N}$ fertilizer); $\mathrm{SOF}_{0}=10 \mathrm{ppm} \mathrm{NAA} ; \mathrm{SOF}_{1}=10 \mathrm{ppm} \mathrm{NAA}+25 \% \mathrm{RDN}$; $\mathrm{SOF}_{2}=10 \mathrm{ppm} \mathrm{NAA}+50 \% \mathrm{RDN} ; \mathrm{SOF}_{3}=10 \mathrm{ppm} \mathrm{NAA}+75 \% \mathrm{RDN} ; \mathrm{SOF}_{4}=10 \mathrm{ppm} \mathrm{NAA}$ $+100 \% \mathrm{RDN} ; \mathrm{SSF}_{0}=$ Foliar spray of $20 \mathrm{ppm} \mathrm{NAA}$; and $\mathrm{SSF}_{1}=$ Foliar spray of $20 \mathrm{ppm} \mathrm{NAA}+$ $25 \% \mathrm{RDN}$.

Plant samples were collected randomly. Dry shoot and root of three different stages viz. flowering, grain filling and harvest and grain after harvest for both the sowing time were grinded into powder and then used for the determination of NPK content. Uptake of NPK by shoot, root and grain and NUE of shoot, root, grain and total plant was calculated using the formulae of Nyborg et al. (1995). Data were analyzed statistically, and treatment means were compared by LSD test at 5\% level of significance (Steel et al. 1997).

\section{Results and Discussion}

Results (Table 1) revealed that in both the sowing time, application of NAA in combination with different doses of $\mathrm{N}$ fertilizer had significant effect on NPK uptake by shoot and root of BARI Gom-25 at flowering stage. At this stage, significantly higher NPK uptake by shoot and root was obtained from seed soaking in $10 \mathrm{ppm}$ NAA in combination with $75 \% \mathrm{~N}$ fertilizer $\left(\mathrm{SOF}_{3}\right)$ in both sowing time except $\mathrm{N}$ uptake by shoot due to 10 ppm NAA with $100 \% \mathrm{~N}$ level $\left(\mathrm{SOF}_{4}\right)$ of both sowing time and $\mathrm{K}$ uptake by root due to $10 \mathrm{ppm}$ NAA with $50 \% \mathrm{~N}$ level $\left(\mathrm{SOF}_{2}\right)$ of November 22 sown wheat.

In both the sowing times, $\mathrm{P}$ uptake by root due to $10 \mathrm{ppm}$ NAA with $75 \% \mathrm{~N}$ fertilizer was statistically identical to $10 \mathrm{ppm}$ NAA with $50 \% \mathrm{~N}$ fertilizer. Results also revealed that NPK uptake by shoot and root due to $10 \mathrm{ppm}$ NAA in combination with 50,75 and 100\% N treatments $\left(\mathrm{SOF}_{2}, \mathrm{SOF}_{3}, \mathrm{SOF}_{4}\right)$ were significantly higher than that of recommended dose of fertilizer $\mathrm{F}_{4}$ ) in both the sowing times having an exception of $\mathrm{N}$ uptake by root due to $\mathrm{SOF}_{4}$ treatment. The 


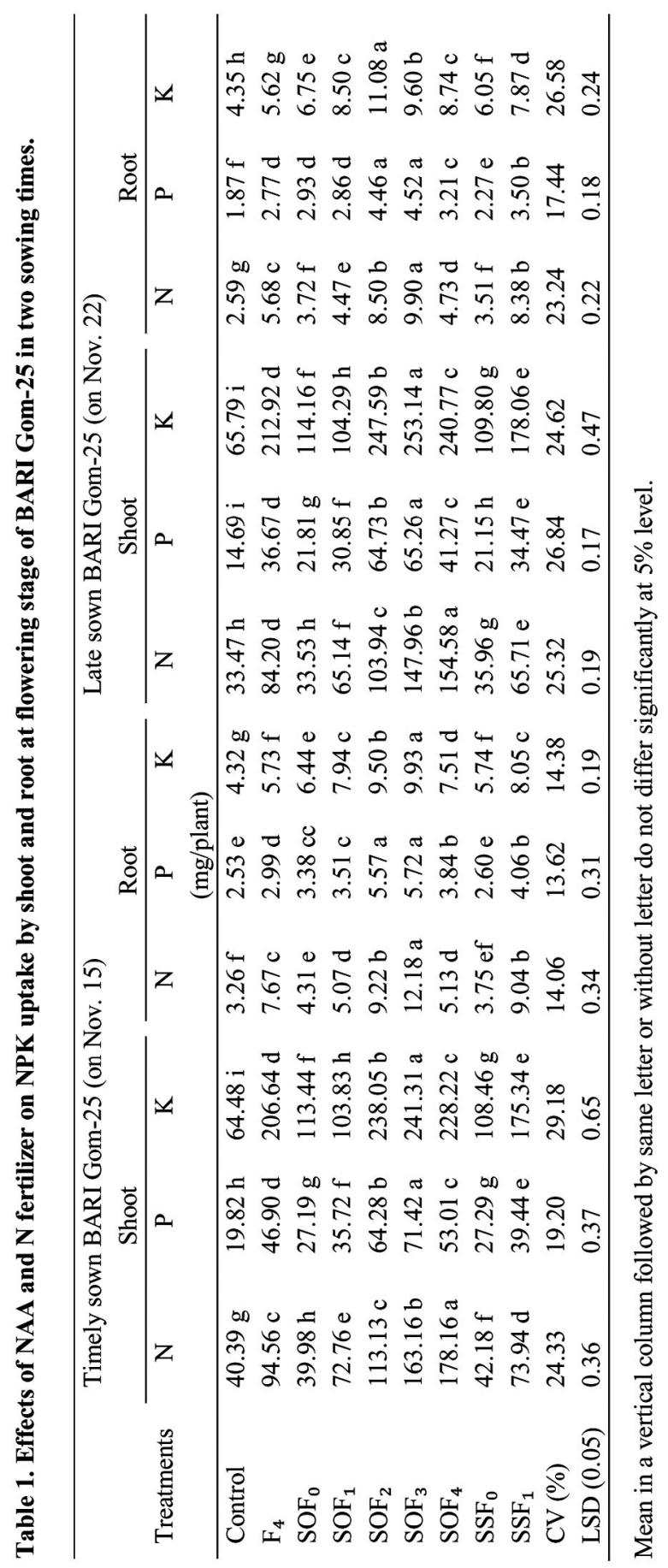


amount of $\mathrm{N}$ and $\mathrm{P}$ uptake by timely sown BARI Gom- 25 were comparatively higher than those of late sown. However, reverse trend was observed in case of $\mathrm{K}$ uptake by shoot and root following all the treatments. Application of nitrogen significantly increased $\mathrm{N}$ and $\mathrm{P}$ uptake of wheat in different treatments in comparison to control (Chaturvedi 2006). However, variation in NPK uptake by two varieties of rice at flowering stage was observed by Adam et al. (2012). In addition, Islam and Jahan (2016b) reported that P uptake influenced both positively and negatively depending on the concentration of NAA and N-levels.

At grain filling stage, NAA in combination with different doses of $\mathrm{N}$ fertilizer had significant response on NPK uptake by shoot and root of both timely and late sown BARI Gom-25 (Table 2). Findings showed that application of NAA in combination with different N-levels $\left(\mathrm{SOF}_{0}, \mathrm{SOF}_{1}\right.$, $\mathrm{SOF}_{2}, \mathrm{SOF}_{3}, \mathrm{SOF}_{4}, \mathrm{SSF}_{0}, \mathrm{SSF}_{1}$ ) had higher $\mathrm{N}$ uptake by shoot and $\mathrm{P}$ and $\mathrm{K}$ uptake by root than that of $100 \%$ fertilizer $\left(\mathrm{F}_{4}\right)$ with appreciable variations at both sowing time, the only exception being $\mathrm{K}$ uptake by root due to $\mathrm{SOF}_{3}$ treatment sown on November 15 . But, $\mathrm{P}$ and $\mathrm{K}$ uptake by shoot and $\mathrm{N}$ uptake by root had significantly higher value mostly from $\mathrm{SOF}_{3}$ and $\mathrm{SOF}_{4}$ treatments at both sowing times.

The highest NPK uptake by shoot was recorded from $\mathrm{SOF}_{4}$ treatment in both the sowing time. However, in case of root, only $\mathrm{N}$ uptake was found highest due to $\mathrm{SOF}_{4}$ treatment. The second highest $\mathrm{N}$ and $\mathrm{P}$ uptake by shoot at both the sowing time and $\mathrm{N}$ uptake by root of late sown BARI Gom-25 were from $\mathrm{SOF}_{3}$ treatment. Findings also showed that BARI Gom-25 uptake more nutrient when sown in November 15 than November 22 in most of the cases. Results of Islam and Jahan (2016b) on BARI Gom-26 revealed that N uptake by shoot and root and K uptake by root at grain filling stage increased due to application of NAA at varying N levels where, 25 ppm NAA in combination $75 \% \mathrm{~N}$ fertilizer produced maximum value. The author also reported that $\mathrm{P}$ uptake by both shoot and root increased following NAA at varying $\mathrm{N}$ levels but with a few exceptions.

NPK uptake by shoot, root and grain was significantly influenced by application of NAA treatments in combination with $\mathrm{N}$ fertilizer in both the sowing times (Table 3). In comparison to the full dose of fertilizer $\left(\mathrm{F}_{4}\right)$, significantly highest NPK uptake by shoot, root and grain was recorded from seed soaking in $10 \mathrm{ppm}$ NAA in combination with $75 \% \mathrm{~N}$ fertilizer $\left(\mathrm{SOF}_{3}\right)$ except $\mathrm{P}$ and $\mathrm{K}$ uptake by root in both the sowing time. Seed soaking in $10 \mathrm{ppm}$ NAA in combination $100 \% \mathrm{~N}$ treatment $\left(\mathrm{SOF}_{4}\right)$ also showed significantly higher uptake value than $\mathrm{F}_{4}$ treatment. Results also indicated that NAA treatments in combination with different doses of $\mathrm{N}$ fertilizers had better stimulation on NPK uptake by shoot and NP uptake by root when sown in November 15 than November 22 in most of the cases. However, K uptake by root showed reverse trend. Significantly maximum NPK uptake by grain were also obtained from $\mathrm{SOF}_{3}$ treatment followed by $\mathrm{SOF}_{4}$ treatments in both sowing times with significant variation between them.

Increased application of nitrogen showed increased uptake of $\mathrm{N}$ by straw and grain in barley (Alam et al. 2005). Variable uptake of N, P and $\mathrm{K}$ due to application of different nitrogen levels in wheat were also reported by Chaturvedi (2006) and Laghari et al. (2010). Purbey and Sen (2007) reported that the N, P and $\mathrm{K}$ content of Fenugreek and their uptake in seed and straw were recorded highest from 20 ppm NAA which was closely followed by 10 ppm NAA treatment. Application of NAA at varying nitrogen levels had mostly beneficial effect on N, P and K content of grain of BARI Gom-26 where, the maximum N content of grain was due to 25 ppm NAA in combination with 75\% N fertilizer (Islam and Jahan 2016b). However, Adam et al. (2012) found both increase and decrease in NPK content of grain depending on the concentration of NAA and rice variety. Thus, the results are in conformity with those of previous workers.

Results presented in Table 4 indicated that NUE was significantly influenced by NAA at different $\mathrm{N}$ levels. At flowering stage, significantly higher NUE of shoot and total plant was 


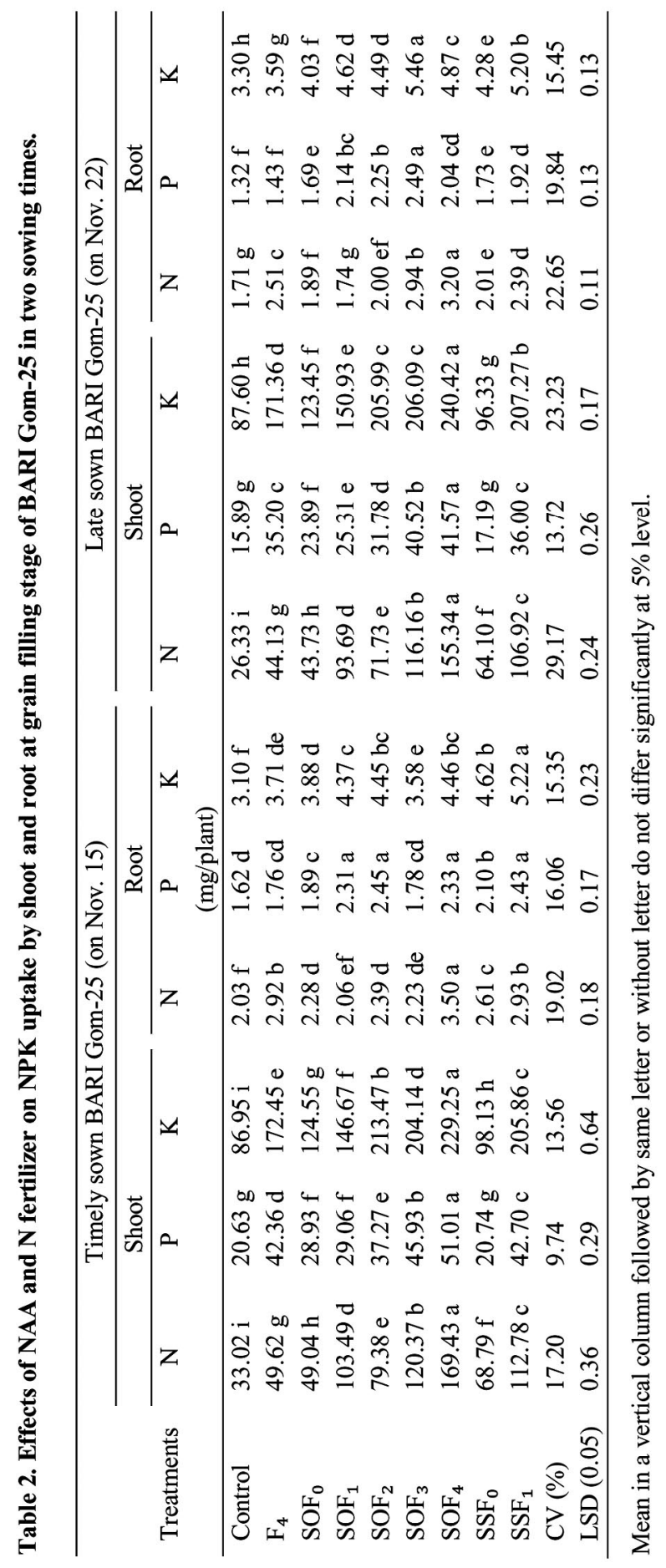


Table 3. Effects of NAA and N fertilizer on NPK uptake by shoot, root and grain at harvest of BARI Gom-25 in two sowing times.

\begin{tabular}{|c|c|c|c|c|c|c|c|c|c|}
\hline \multirow[b]{3}{*}{$\begin{array}{l}\text { Treat- } \\
\text { ments }\end{array}$} & \multicolumn{9}{|c|}{ Timely sown BARI Gom-25 (on Nov. 15) } \\
\hline & \multicolumn{3}{|c|}{ Shoot } & \multicolumn{3}{|c|}{ Root } & \multicolumn{3}{|c|}{ Grain } \\
\hline & $\mathrm{N}$ & $\mathrm{P}$ & $\mathrm{K}$ & $\mathrm{N}$ & $\begin{array}{c}\mathrm{P} \\
\text { (mg/plant) }\end{array}$ & $\mathrm{K}$ & $\mathrm{N}$ & $\mathrm{P}$ & $\mathrm{K}$ \\
\hline Control & $37.58 \mathrm{~g}$ & $14.87 \mathrm{~g}$ & $157.84 \mathrm{f}$ & $3.69 \mathrm{c}$ & $1.37 \mathrm{~d}$ & $3.60 \mathrm{a}$ & $74.42 \mathrm{~g}$ & $10.98 \mathrm{~g}$ & $7.29 \mathrm{~g}$ \\
\hline $\mathrm{F}_{4}$ & $72.48 \mathrm{c}$ & $28.01 \mathrm{c}$ & $216.23 \mathrm{~d}$ & $4.32 \mathrm{~b}$ & $1.21 \mathrm{e}$ & $2.98 \mathrm{~cd}$ & $172.64 \mathrm{~d}$ & $24.22 \mathrm{~d}$ & $22.42 \mathrm{~d}$ \\
\hline $\mathrm{SOF}_{0}$ & $42.77 \mathrm{f}$ & $12.44 \mathrm{i}$ & $146.02 \mathrm{~h}$ & $3.05 \mathrm{e}$ & $1.37 \mathrm{~d}$ & $3.06 \mathrm{a}$ & $65.69 \mathrm{i}$ & $9.84 \mathrm{~h}$ & $8.55 \mathrm{f}$ \\
\hline $\mathrm{SOF}_{1}$ & $47.74 \mathrm{f}$ & $19.29 \mathrm{~d}$ & $151.07 \mathrm{~g}$ & $3.62 \mathrm{~cd}$ & $1.41 \mathrm{~cd}$ & $3.22 \mathrm{~b}$ & $121.72 \mathrm{f}$ & $17.97 \mathrm{f}$ & $17.77 \mathrm{e}$ \\
\hline $\mathrm{SOF}_{2}$ & $60.33 \mathrm{~d}$ & $16.48 \mathrm{f}$ & $181.13 \mathrm{e}$ & $5.07 \mathrm{a}$ & $1.50 \mathrm{bc}$ & $2.36 \mathrm{e}$ & $173.51 \mathrm{c}$ & $24.80 \mathrm{c}$ & $24.80 \mathrm{c}$ \\
\hline $\mathrm{SOF}_{3}$ & $97.81 \mathrm{a}$ & $34.67 \mathrm{a}$ & $301.88 \mathrm{a}$ & $4.85 \mathrm{a}$ & $2.20 \mathrm{a}$ & $2.84 \mathrm{~d}$ & $220.88 \mathrm{a}$ & $29.45 \mathrm{a}$ & $28.75 \mathrm{a}$ \\
\hline $\mathrm{SOF}_{4}$ & 88.19 b & $31.48 \mathrm{~b}$ & $296.47 \mathrm{~b}$ & $4.05 \mathrm{~b}$ & $1.58 \mathrm{~b}$ & $2.07 \mathrm{f}$ & $202.37 \mathrm{~b}$ & $27.90 \mathrm{~b}$ & $26.78 \mathrm{~b}$ \\
\hline $\mathrm{SSF}_{0}$ & $27.59 \mathrm{~h}$ & $13.00 \mathrm{~h}$ & $120.80 \mathrm{i}$ & $3.31 \mathrm{de}$ & $2.17 \mathrm{a}$ & $2.85 \mathrm{~d}$ & $68.22 \mathrm{~h}$ & $9.93 \mathrm{~h}$ & $6.80 \mathrm{~g}$ \\
\hline $\mathrm{SSF}_{1}$ & $50.82 \mathrm{e}$ & $17.97 \mathrm{e}$ & $218.43 \mathrm{c}$ & $3.65 \mathrm{c}$ & $1.57 \mathrm{~b}$ & $2.35 \mathrm{e}$ & $150.14 \mathrm{e}$ & $21.46 \mathrm{e}$ & $17.19 \mathrm{e}$ \\
\hline CV (\%) & 18.49 & 17.94 & 13.25 & 17.48 & 21.91 & 16.93 & 40.64 & 37.80 & 25.95 \\
\hline $\begin{array}{l}\text { LSD } \\
(0.05)\end{array}$ & 0.47 & 0.49 & 0.49 & 0.33 & 0.12 & 0.16 & 0.86 & 0.39 & 0.58 \\
\hline
\end{tabular}

Right hand side of table

\begin{tabular}{|c|c|c|c|c|c|c|c|c|}
\hline \multicolumn{9}{|c|}{ Late sown BARI Gom-25 (on Nov. 22) } \\
\hline \multicolumn{3}{|c|}{ Shoot } & \multicolumn{3}{|c|}{ Root } & \multicolumn{3}{|c|}{ Grain } \\
\hline $\mathrm{N}$ & $\mathrm{P}$ & $\mathrm{K}$ & $\mathrm{N}$ & $\begin{array}{c}\mathrm{P} \\
(\mathrm{mg} / \text { plant })\end{array}$ & $\mathrm{K}$ & $\mathrm{N}$ & $\mathrm{P}$ & $\mathrm{K}$ \\
\hline $19.69 \mathrm{~g}$ & $7.68 \mathrm{f}$ & $212.67 \mathrm{c}$ & $2.71 \mathrm{~d}$ & $0.20 \mathrm{~g}$ & $4.99 \mathrm{~d}$ & $80.97 \mathrm{i}$ & $12.25 \mathrm{~g}$ & $9.18 \mathrm{i}$ \\
\hline $33.72 \mathrm{~d}$ & $12.46 \mathrm{~b}$ & $146.32 \mathrm{e}$ & $4.39 \mathrm{a}$ & $1.16 \mathrm{a}$ & $5.25 \mathrm{c}$ & $171.09 \mathrm{c}$ & $24.15 \mathrm{c}$ & $23.08 \mathrm{~d}$ \\
\hline $16.51 \mathrm{~h}$ & $9.51 \mathrm{e}$ & $115.82 \mathrm{~g}$ & $2.14 \mathrm{e}$ & $0.75 \mathrm{e}$ & $4.89 \mathrm{~d}$ & $89.09 \mathrm{~h}$ & $13.82 \mathrm{f}$ & $12.52 \mathrm{~g}$ \\
\hline $24.25 \mathrm{e}$ & $9.39 \mathrm{e}$ & $123.50 \mathrm{f}$ & $3.26 \mathrm{c}$ & $0.87 \mathrm{~d}$ & $4.40 \mathrm{e}$ & $133.71 \mathrm{f}$ & $19.54 \mathrm{e}$ & $19.49 \mathrm{e}$ \\
\hline $47.21 \mathrm{a}$ & $10.60 \mathrm{~d}$ & $197.94 \mathrm{~d}$ & $3.91 \mathrm{~b}$ & $0.98 \mathrm{c}$ & $3.99 \mathrm{f}$ & $166.56 \mathrm{~d}$ & $23.88 \mathrm{c}$ & $24.13 \mathrm{c}$ \\
\hline $39.86 \mathrm{c}$ & $12.72 \mathrm{a}$ & $249.00 \mathrm{a}$ & $4.34 \mathrm{a}$ & $0.36 \mathrm{f}$ & $3.73 \mathrm{~g}$ & $213.08 \mathrm{a}$ & $28.58 \mathrm{a}$ & $28.20 \mathrm{a}$ \\
\hline $43.11 \mathrm{~b}$ & $9.48 \mathrm{e}$ & $240.91 \mathrm{~b}$ & $4.40 \mathrm{a}$ & $1.06 \mathrm{~b}$ & $2.73 \mathrm{~h}$ & $190.04 \mathrm{~b}$ & $26.57 \mathrm{~b}$ & $26.08 \mathrm{~b}$ \\
\hline $11.82 \mathrm{i}$ & $7.05 \mathrm{~g}$ & $75.14 \mathrm{~h}$ & $2.09 \mathrm{f}$ & $1.04 \mathrm{bc}$ & $8.92 \mathrm{a}$ & $91.88 \mathrm{~g}$ & $13.91 \mathrm{f}$ & $10.13 \mathrm{~h}$ \\
\hline $20.71 \mathrm{f}$ & $11.20 \mathrm{c}$ & $72.32 \mathrm{i}$ & $4.49 \mathrm{a}$ & $1.05 \mathrm{~b}$ & $8.52 \mathrm{~b}$ & $149.90 \mathrm{e}$ & $20.92 \mathrm{~d}$ & $18.01 \mathrm{f}$ \\
\hline 22.55 & 18.64 & 14.72 & 17.14 & 18.92 & 18.04 & 31.61 & 27.91 & 25.39 \\
\hline 0.13 & 0.15 & 0.34 & 0.15 & 0.06 & 0.11 & 0.68 & 0.57 & 0.48 \\
\hline
\end{tabular}

Mean in a vertical column followed by same letter or without letter do not differ significantly at $5 \%$ level. 
Table 4. Effects of NAA and N fertilizer on NUE of BARI Gom-25 at three different stages of growth in two sowing times.

\begin{tabular}{|c|c|c|c|c|c|c|c|c|c|c|}
\hline \multirow[b]{3}{*}{$\begin{array}{l}\text { Treat- } \\
\text { ments }\end{array}$} & \multicolumn{10}{|c|}{ Timely sown BARI Gom-25 (on Nov. 15) } \\
\hline & \multicolumn{3}{|c|}{ Flowering } & \multicolumn{3}{|c|}{ Grain filling } & \multicolumn{3}{|c|}{ Harvest } & \multirow[b]{2}{*}{ Total } \\
\hline & Shoot & Root & Total & Shoot & $\begin{array}{l}\text { Root } \\
\mathrm{Kg} \mathrm{N} / \mathrm{Kg} \mathrm{N}\end{array}$ & Total & Shoot & Root & Grain & \\
\hline Control & - & - & - & - & - & - & - & - & - & - \\
\hline $\mathrm{F}_{4}$ & $0.217 \mathrm{f}$ & $0.018 \mathrm{c}$ & $0.235 \mathrm{f}$ & $0.066 \mathrm{f}$ & $0.004 \mathrm{a}$ & $0.070 \mathrm{f}$ & $0.140 \mathrm{~d}$ & $0.003 \mathrm{c}$ & $0.393 \mathrm{e}$ & $0.536 \mathrm{f}$ \\
\hline $\mathrm{SOF}_{0}$ & - & - & - & - & - & - & - & - & - & - \\
\hline $\mathrm{SOF}_{1}$ & $0.504 \mathrm{~d}$ & $0.012 \mathrm{~d}$ & $0.516 \mathrm{e}$ & $0.838 \mathrm{a}$ & $-0.003 \mathrm{c}$ & $0.835 \mathrm{a}$ & $0.076 \mathrm{e}$ & $0.009 \mathrm{~b}$ & $0.862 \mathrm{~b}$ & $0.947 \mathrm{~d}$ \\
\hline $\mathrm{SOF}_{2}$ & $0.585 \mathrm{~b}$ & $0.039 \mathrm{~b}$ & $0.624 \mathrm{~b}$ & $0.243 \mathrm{e}$ & $0.001 \mathrm{~b}$ & $0.244 \mathrm{e}$ & $0.141 \mathrm{~d}$ & $0.016 \mathrm{a}$ & $0.863 \mathrm{~b}$ & $1.020 \mathrm{c}$ \\
\hline $\mathrm{SOF}_{3}$ & $0.648 \mathrm{a}$ & $0.041 \mathrm{~b}$ & $0.689 \mathrm{a}$ & $0.375 \mathrm{~d}$ & $0.000 \mathrm{~b}$ & $0.375 \mathrm{~d}$ & $0.290 \mathrm{~b}$ & $0.009 \mathrm{~b}$ & $0.817 \mathrm{c}$ & $1.116 \mathrm{~b}$ \\
\hline $\mathrm{SOF}_{4}$ & $0.553 \mathrm{c}$ & $0.003 \mathrm{e}$ & $0.556 \mathrm{~d}$ & $0.480 \mathrm{c}$ & $0.005 \mathrm{a}$ & $0.485 \mathrm{c}$ & $0.182 \mathrm{c}$ & $0.004 \mathrm{c}$ & $0.547 \mathrm{~d}$ & $0.733 \mathrm{e}$ \\
\hline $\mathrm{SSF}_{0}$ & - & - & - & - & - & - & - & - & - & - \\
\hline $\mathrm{SSF}_{1}$ & $0.489 \mathrm{e}$ & $0.081 \mathrm{a}$ & $0.570 \mathrm{c}$ & $0.677 \mathrm{~b}$ & $0.005 \mathrm{a}$ & $0.682 b$ & $0.357 \mathrm{a}$ & $0.005 \mathrm{bc}$ & $1.260 \mathrm{a}$ & $1.622 \mathrm{a}$ \\
\hline $\mathrm{CV}(\%)$ & 27.89 & 38.72 & 27.54 & 28.69 & 18.93 & 51.97 & 29.58 & 28.07 & 35.23 & 34.72 \\
\hline $\begin{array}{l}\text { LSD } \\
(0.05)\end{array}$ & 0.002 & 0.004 & 0.004 & 0.005 & 0.002 & 0.004 & 0.005 & 0.004 & 0.011 & 0.014 \\
\hline
\end{tabular}

\section{Right hand side of the table}

\begin{tabular}{|c|c|c|c|c|c|c|c|c|c|}
\hline \multirow{2}{*}{\multicolumn{3}{|c|}{ Flowering }} & \multicolumn{7}{|c|}{ I ate sown BARI Gom-25 (on Nov. 22) } \\
\hline & & & & Grain fillin & & & Harvest & & \\
\hline Shoot & Root & Total & Shoot & Root & Total & Shoot & Root & Grain & Total \\
\hline- & - & - & - & - & - & - & - & - & - \\
\hline $0.203 \mathrm{e}$ & $0.012 \mathrm{~d}$ & $0.215 \mathrm{f}$ & $0.071 \mathrm{f}$ & $0.003 \mathrm{bc}$ & $0.074 \mathrm{f}$ & $0.056 \mathrm{f}$ & $0.007 \mathrm{~d}$ & $0.360 \mathrm{f}$ & $0.423 \mathrm{f}$ \\
\hline- & - & - & - & - & - & - & - & - & - \\
\hline $0.486 \mathrm{c}$ & $0.012 \mathrm{~d}$ & $0.498 \mathrm{~d}$ & $0.769 \mathrm{a}$ & $-0.002 d$ & $0.767 \mathrm{a}$ & $0.119 \mathrm{~d}$ & $0.017 \mathrm{~b}$ & $0.686 \mathrm{~b}$ & $0.822 \mathrm{c}$ \\
\hline $0.563 \mathrm{~b}$ & $0.038 \mathrm{~b}$ & $0.601 \mathrm{~b}$ & $0.224 \mathrm{e}$ & $0.001 \mathrm{c}$ & $0.225 \mathrm{e}$ & $0.246 \mathrm{a}$ & $0.014 \mathrm{c}$ & $0.620 \mathrm{~d}$ & $0.880 \mathrm{~b}$ \\
\hline $0.602 \mathrm{a}$ & $0.032 \mathrm{c}$ & $0.634 \mathrm{a}$ & $0.381 \mathrm{~d}$ & $0.006 \mathrm{a}$ & $0.387 \mathrm{~d}$ & $0.123 \mathrm{c}$ & $0.012 \mathrm{c}$ & $0.653 \mathrm{c}$ & $0.788 \mathrm{~d}$ \\
\hline $0.484 \mathrm{c}$ & $0.004 \mathrm{e}$ & $0.488 \mathrm{e}$ & $0.446 \mathrm{c}$ & $0.005 \mathrm{ab}$ & $0.451 \mathrm{c}$ & $0.106 \mathrm{e}$ & $0.009 \mathrm{~d}$ & $0.404 \mathrm{e}$ & $0.519 \mathrm{e}$ \\
\hline- & - & - & - & - & - & - & - & - & - \\
\hline $0.459 \mathrm{~d}$ & $0.075 \mathrm{a}$ & $0.534 \mathrm{c}$ & $0.659 \mathrm{~b}$ & $0.006 \mathrm{a}$ & $0.665 \mathrm{~b}$ & $0.137 \mathrm{~b}$ & $0.037 \mathrm{a}$ & $0.893 \mathrm{a}$ & $1.067 \mathrm{a}$ \\
\hline 27.88 & 38.93 & 27.89 & 27.02 & 10.99 & 26.47 & 34.31 & 36.81 & 30.21 & 29.49 \\
\hline 0.002 & 0.002 & 0.003 & 0.002 & 0.002 & 0.002 & 0.002 & 0.002 & 0.007 & 0.006 \\
\hline
\end{tabular}

Mean in a vertical column followed by same letter or without letter do not differ significantly at $5 \%$ level. 
obtained from seed soaking of $10 \mathrm{ppm}$ NAA in combination with $75 \% \mathrm{~N}$ fertilizer $\left(\mathrm{SOF}_{3}\right)$ in case of both sowing times. Whereas, at grain filling stage, the same response was recorded from seed soaking of $10 \mathrm{ppm}$ NAA in combination with $25 \% \mathrm{~N}$ level $\left(\mathrm{SOF}_{1}\right)$. Results revealed that at both flowering and grain filling stage, significantly higher NUE of root was obtained from $20 \mathrm{ppm}$ NAA in combination with $25 \% \mathrm{~N}$ treatment $\left(\mathrm{SSF}_{1}\right)$. Findings also revealed that at harvest $\mathrm{SSF}_{1}$ treatment showed significantly higher NUE except those recorded from root of November 15 sown and shoot of November 22 sown BARI Gom-25. Nitrogen use efficiency gradually decreased with subsequent delay in sowing and influence of nitrogen fertilizer was found to increase significantly up to $90 \mathrm{~kg} \mathrm{~N} / \mathrm{ha}$ in barley (Alam et al. 2005). In an experiment with BARI Gom-26, Islam and Jahan (2016b) recorded the highest NUE of shoot and total plant from $50 \mathrm{ppm}$ NAA in combination with $50 \% \mathrm{~N}$ fertilizer at flowering stage, whereas, from $25 \mathrm{ppm}$ NAA in combination with $75 \% \mathrm{~N}$ fertilizer at grain filling stage.

\section{Acknowledgements}

Authors wish to thank Professor Dr. Sirajul Hoque, Ex-Chairman, Department of Soil, Water and Environment, University of Dhaka for giving permission to analyze plant sample in his laboratory and also for his kind cooperation and valuable guidance during the investigation. Authors are also thankful to Dr. Moniruzzaman, Senior Scientific Officer of Bangladesh Council of Scientific and Industrial research (BCSIR) for his sincere cooperation during laboratory analysis.

\section{References}

Adam AMMG and Jahan N 2011. Effects of naphthalene acetic acid on yield attributes and yield of two varieties of rice (Oryza sativa L.). Bangladesh J. Bot. 40(1): 97-100.

Adam AMMG, Jahan N and Hoque S 2012. Effects of naphthalene acetic acid on nutrient uptake by two varieties of rice (Oryza sativa L.). Dhaka Univ. J. Biol. Sci. 21(1): 9-15.

Akter R 2016. Responses of BARI Sweet Corn-1 (Zea mays L.) to naphthalene acetic acid at various nitrogen fertilizer levels. MS Thesis, Department of Botany, Jagannath University, Dhaka, Bangladesh. 158 pp.

Alam MZ, Haider SA and Paul NK 2005. Effects of sowing time and nitrogen fertilizer on barley (Hordeum vulgare L.). Bangladesh J. Bot. 34(1): 27-30.

Canfield DE, Glazer AN, Falkowski PG 2010. The evolution and future of earth's nitrogen cycle. Science 330: 192-196.

Carranca C 2012. Nitrogen use efficiency by annual and perennial crops. In: Farming for food and water security. Lichtfouse E. (ed.). Springer Science Business Media: Dordrecht, The Netherlands. pp. 57-82.

Chaturvedi I 2006. Effects of different nitrogen levels on growth, yield and nutrient uptake of wheat (Triticum aestivum L.). Internat. J. Agric. Sci. 2(2): 372-374.

Chowdhury MAH and Hassan MS 2013. Handbook of Agricultural Technology. Bangladesh Agricultural Technology. Bangladesh Agric. Res. Council, Farmgate, Dhaka. 230 pp.

Fertilizer Recommendation Guide 2012. Bangladesh Agricultural Research Council, Farmgate, Dhaka-1215. 274 pp.

Islam S and Jahan N 2016a. Growth and yield responses of Triticum aestivum L. var. BARI Gom- 26 following application of naphthalene acetic acid (NAA) at varying nitrogen levels. Bangladesh J. Bot. 45(2): 411-418.

Islam S and Jahan N 2016b. Effects of NAA and different nitrogen levels on nutrient uptake by BARI Gom26 (Triticum aestivum L.). J. Asiat. Soc. Bangladesh Sci. 42(1): 69-76.

Jackson ML 1973. Soil Chemical Analysis. Asia Pub. House, Bombey, Calcutta, New Delhi, Madras. pp. 151-154. 
Jahan N and Adam AMMG 2013. Growth and yield responses of BARI Gom-26 (Triticum aestivum L.) to naphthalene acetic acid. Dhaka Univ. J. Biol. Sci. 22(2): 119-125.

Jahan N and Adam AMMG 2014. Changes in biochemical component of rice following NAA application. J. Asiatic Soc. Bangladesh, Sci. 40(2): 173-178.

Laghari GM, Oad FC, Tunio S, Gandahi AW, Siddiqui MH, Jagirani AW and Oad SM 2010. Growth, yield and nutrient uptake of various wheat cultivars under different fertilizer regimes. Sarhad. J. Agric. 26(4): 489-497.

Marr IL and Cresser MS 1983. Environmental chemical analysis. University of California. International Textbook Co. 258 pp.

Murphy J and Riley JP 1962. A modified simple solution method for determination of phosphate in saturated water. Analytica. Chemica. Acta. 27: 31-36.

Nyborg M, Solberg ED, Izaurralde RC, Malhi SS and Molina-Ayala M 1995. Influence of long term tilleage, straw and fertilizer on barley yield, plant $\mathrm{N}$ uptake and soil-N balance. Soil and Tillage Res. 36: 165174.

Purbey SK and Sen NL 2007. Effect of bioinoculates and bioregulators on yield and nutrient uptake by fenugreek (Trigonellafoenum graecum L.). Indian J. Agric. Res. 41(2): 154-156.

Steel RGD, Torrie JH and Dickey DA 1997. Principles and procedures of statistics. McGraw Hill Book Co. Inc. New York. 666 pp.

Vidal I, Longeri L and Hetier JM 1999. Nitrogen uptake and chlorophyll meter measurements in spring wheat. Nutrient Cycling in Agroecosystems. 55: 1-6.

(Manuscript received on 21 April, 2019; revised on 26 December, 2019) 